\title{
Highly thermostable xylanase production from a thermophilic Geobacillus sp. strain WSUCF1 utilizing lignocellulosic biomass
}

\author{
Aditya Bhalla ${ }^{1 \dagger}$, Kenneth M. Bischoff ${ }^{2}$ and Rajesh Kumar Sani ${ }^{1 *}$ \\ 'Department of Chemical and Biological Engineering, South Dakota School of Mines and Technology, Rapid City, SD, \\ USA, ${ }^{2}$ Renewable Product Technology Research Unit, Agricultural Research Service, National Center for Agricultural \\ Utilization Research, U.S. Department of Agriculture, Peoria, IL, USA
}

\section{OPEN ACCESS \\ Edited by:}

Felipe Andres Sarmiento, Swissaustral USA LLC, USA

Reviewed by:

Hailan Piao,

Washington State University Tri-Cities, USA

Noha M. Mesbah,

Suez Canal University, Egypt

*Correspondence:

Rajesh Kumar Sani,

501 East St. Joseph Street,

Rapid City, SD, USA

rajesh.sani@sdsmt.edu

tPresent Address:

Aditya Bhalla,

DOE Great Lakes Bioenergy

Research Center,

Michigan State University,

Lansing, MI, USA

Specialty section: This article was submitted to Process and Industrial Biotechnology, a section of the journal Frontiers in Bioengineering and Biotechnology

Received: 31 March 2015 Accepted: 22 May 2015

Published: 16 June 2015

Citation:

Bhalla A, Bischoff KM and Sani RK (2015) Highly thermostable xylanase production from a thermophilic Geobacillus sp. strain WSUCF1 utilizing lignocellulosic biomass. Front. Bioeng. Biotechnol. 3:84. doi: 10.3389/fbioe.2015.00084
Efficient enzymatic hydrolysis of lignocellulose to fermentable sugars requires a complete repertoire of biomass deconstruction enzymes. Hemicellulases play an important role in hydrolyzing hemicellulose component of lignocellulose to xylooligosaccharides and xylose. Thermostable xylanases have been a focus of attention as industrially important enzymes due to their long shelf life at high temperatures. Geobacillus sp. strain WSUCF1 produced thermostable xylanase activity (crude xylanase cocktail) when grown on xylan or various inexpensive untreated and pretreated lignocellulosic biomasses such as prairie cord grass and corn stover. The optimum $\mathrm{pH}$ and temperature for the crude xylanase cocktail were 6.5 and $70^{\circ} \mathrm{C}$, respectively. The WSUCF1 crude xylanase was found to be highly thermostable with half-lives of 18 and 12 days at 60 and $70^{\circ} \mathrm{C}$, respectively. At $70^{\circ} \mathrm{C}$, rates of xylan hydrolysis were also found to be better with the WSUCF1 secretome than those with commercial enzymes, i.e., for WSUCF1 crude xylanase, Cellic-HTec2, and AccelleraseXY, the percent xylan conversions were 68.9, 49.4, and 28.92, respectively. To the best of our knowledge, WSUCF1 crude xylanase cocktail is among the most thermostable xylanases produced by thermophilic Geobacillus spp. and other thermophilic microbes (optimum growth temperature $\leq 70^{\circ} \mathrm{C}$ ). High thermostability, activity over wide range of temperatures, and better xylan hydrolysis than commercial enzymes make WSUCF1 crude xylanase suitable for thermophilic lignocellulose bioconversion processes.

Keywords: biofuels, corn stover, xylanase, prairie cord grass, thermostable, untreated lignocellulose

\section{Introduction}

Lignocellulosic agricultural and forestry waste materials are the key substrates for second generation biofuels. Lignocellulose contains $20-40 \%$ of hemicellulose, which is a branched heteropolymer consisting of pentose (D-xylose and D-arabinose) and hexose (D-mannose, D-glucose, and D-galactose) sugars with xylose being most abundant (Cano and Palet, 2007; Kumar et al., 2008). Hemicelluloses are classified according to the main sugar in the backbone of the polymer, e.g., xylan $(\beta-1,4$-linked xylose) or mannan ( $\beta$-1,4-linked mannose) (Jørgensen et al., 2007). To obtain these linked sugars, there is a need to effectively break the locked polysaccharides from recalcitrant lignocellulose. There have been various reports published on deconstruction of hemicellulose utilizing hemicellulases (Gao et al., 
2011). Among hemicellulases, endoxylanases and $\beta$-xylosidases are reported to be the main components responsible for effective conversion of xylan fraction of biomass to monomeric xylose (Qing and Wyman, 2011; Bhalla et al., 2014a,b).

Thermophiles have often been proposed as a potential source of industrially relevant thermostable enzymes (Turner et al., 2007; Viikari et al., 2007). For example, thermophilic microbes of various genera, including Bacillus, Geobacillus, Acidothermus, Cellulomonas, Paenibacillus, Thermoanaerobacterium, Actinomadura, Alicyclobacillus, Anoxybacillus, Nesterenkonia, and Enterobacter have been reported to produce thermostable xylanases (Bhalla et al., 2013). Thermostable enzymes have an obvious advantage as catalysts in the lignocellulose conversion processes due to better enzyme accessibility and cell-wall disorganization achieved at high-temperature reaction conditions (Paes and O'Donohue, 2006). Also, high temperature allows better solubility of reactants and products by lowering the viscosities, leading to faster hydrolysis (Viikari et al., 2007). Longer active life under high temperature conditions would make these enzymes favorable for enhanced and efficient biomass conversion. Therefore, to be an effective enzyme, thermostability is the most important attribute for the enzyme utilized under extreme bioprocessing conditions. The present work describes the characterization of highly thermostable endoxylanases (simply referred to as crude xylanase cocktail) produced by Geobacillus sp. strain WSUCF1. Hydrolytic activity of WSUCF1 crude xylanase cocktail was studied, and compared to commercially available enzyme cocktails.

\section{Materials and Methods}

\section{Microorganism, Medium, and Inoculums}

The WSUCF1 strain was identified as Geobacillus sp. and affiliated to phylum Firmicutes by $16 \mathrm{~S}$ rDNA analysis (Rastogi et al., 2010). The WSUCF1 strain was grown at $60^{\circ} \mathrm{C}$ and $\mathrm{pH} 7.0$ in a minimal medium supplemented with xylan $(0.2 \%)$ or lignocellulosic substrates (1\%) as carbon and energy source. The composition of the medium per liter: $0.1 \mathrm{~g}$ nitrilotriacetic acid, $0.05 \mathrm{~g}$ $\mathrm{CaCl}_{2} \cdot 2 \mathrm{H}_{2} \mathrm{O}, 0.1 \mathrm{~g} \mathrm{MgSO}_{4} \cdot 7 \mathrm{H}_{2} \mathrm{O}, 0.01 \mathrm{~g} \mathrm{NaCl}, 0.01 \mathrm{~g} \mathrm{KCl}, 0.3 \mathrm{~g}$ $\mathrm{NH}_{4} \mathrm{Cl}, 0.005 \mathrm{~g}$ methionine, $0.2 \mathrm{~g}$ yeast extract, $0.01 \mathrm{~g}$ casamino acid, $1.8 \mathrm{~g}$ of $85 \% \mathrm{H}_{3} \mathrm{PO}_{4}, 1 \mathrm{ml} \mathrm{FeCl}_{3}$ solution $(0.03 \%)$, and $1 \mathrm{ml}$ of Nitsch's trace solution (Rastogi et al., 2009). Five percent of pre-culture grown was used to inoculate $100 \mathrm{ml}$ of minimal medium containing carbon source in $500 \mathrm{ml}$ Erlenmeyer flasks. The flasks were incubated in a shaker incubator at $60^{\circ} \mathrm{C}, 150 \mathrm{rpm}$ for $96 \mathrm{~h}$. Control flasks contained only carbon source without WSUCF1 cells, for each experiment. After every $12 \mathrm{~h}, 1 \mathrm{ml}$ samples were removed aseptically, and analyzed. Growth was checked by measuring absorbance at $600 \mathrm{~nm}$. Immediately after collection, the samples were centrifuged at $4^{\circ} \mathrm{C}$ and $10,000 \times g$ for $10 \mathrm{~min}$. Supernatant was analyzed for the endoxylanase activity as described below.

\section{Enzyme Assay}

The reaction mixtures contained $0.5 \mathrm{ml}$ of $1 \%(\mathrm{w} / \mathrm{v})$ Birchwood xylan (Sigma-Aldrich) in phosphate buffer ( $100 \mathrm{mM}, \mathrm{pH} 6.5)$ and $0.5 \mathrm{ml}$ of an appropriate dilution of enzyme. The enzyme-substrate reaction was carried out at $70^{\circ} \mathrm{C}$ for $10 \mathrm{~min}$ and reaction was stopped by the addition of $1.5 \mathrm{ml} 3,5$-dinitrosalicylic acid (DNSA) solution, boiled for $10 \mathrm{~min}$, and then cooled on ice for color stabilization. The optical absorbance was measured at $540 \mathrm{~nm}$ and the amounts of liberated reducing sugars (xylose equivalents) were estimated against a xylose standard curve.

\section{Parametric Optimization for Xylanase Cocktail Production}

Physical parameters for crude xylanase cocktail activity production were optimized by maintaining all factors constant except the one being studied. Effect of $\mathrm{pH}$ on enzyme production was assessed by cultivating the WSUCF1 strain in non-buffered growth media of $\mathrm{pH} 5.0-9.0$, at $60^{\circ} \mathrm{C}$ for $96 \mathrm{~h}$. The $\mathrm{pH}$ of the medium was adjusted using $5 \mathrm{M} \mathrm{NaOH}$ or $6 \mathrm{~N} \mathrm{HCl}$. The effect of temperature was studied by growing the microbe at different temperatures $\left(50-80^{\circ} \mathrm{C}\right), \mathrm{pH} 7.0$ for $96 \mathrm{~h}$. Effect of various easily available inexpensive carbon and energy sources including untreated prairie cord grass (PCG) $1 \%$, untreated corn stover (CS) $1 \%$, thermo-mechanically pretreated prairie cord grass (PPCG) $1 \%$, or thermo-mechanically pretreated corn stover (PCS) 1\% was studied for crude xylanase activity. Growth conditions for the WSUCF1 utilizing these substrates are described above under Section "Microorganism, Medium, and Inoculums." Thermo-mechanical pretreatment of the CS and PCG was carried out in a single-screw extruder as described earlier (Kannadhason et al., 2009).

\section{Characterization of the Crude Xylanases}

Sodium dodecyl sulfate-polyacrylamide gel electrophoresis (SDS-PAGE) was performed as described by Laemmli (1970). Ten milliliters of supernatant from each growth flask containing different substrates (xylan, CS, PCS, PCS, and PPCG as substrate) were passed through Amicon Ultra-15 - Millipore (3 kDa cut-off) to $10 \times$ concentrate the protein. To obtain zymogram of crude endoxylanase and $\beta$-xylosidase activity following SDSPAGE, samples ( $10 \mu \mathrm{l}$ of concentrated protein) were mixed with $10 \mu \mathrm{l} 2 \times \mathrm{SDS}$ sample buffer, and heated to $95^{\circ} \mathrm{C}$ for $1 \mathrm{~min}$ prior to loading on gel. For endoxylanase, sample was loaded onto a $12 \%$ SDS-PAGE gel containing $0.1 \%(\mathrm{w} / \mathrm{v}$ ) oat spelt xylan (OSX) polymerized within the gel matrix whereas for $\beta$-xylosidase, gel was separately incubated with the substrate for $30 \mathrm{~min}$, i.e., $0.1 \mathrm{mg} / \mathrm{ml}$ 4-methylumbelliferyl- $\beta$-d-xylopyranoside in phosphate buffered saline, $\mathrm{pH}$ 5.9. Current (150 V constant voltage) was passed through the gel until the bromophenol blue dye-front migrated to the bottom of the gel. The gel was washed successively with the following for 30 min each: $20 \%$ isopropanol in phosphate buffer saline (PBS, $100 \mathrm{mM}, \mathrm{pH}$ 5.9), $8 \mathrm{M}$ urea in PBS, and PBS (pH 5.9) three times. For endoxylanase, the gel was incubated in $\mathrm{PBS}$ ( $\mathrm{pH} 5.9$ ) overnight at $37^{\circ} \mathrm{C}$. The gel was stained with Congo Red $(1 \mathrm{mg} / \mathrm{ml})$ for $30 \mathrm{~min}$, and de-stained with $1 \mathrm{M} \mathrm{NaCl}$ in PBS until clear bands indicating xylanase activity were visible. For the detection of $\beta$-xylosidase activity, gel was examined for fluorescence on a UV light box indicating $\beta$-xylosidase activity.

The relative xylanase activity using 1\% (w/v) Birchwood xylan was determined at various $\mathrm{pHs}$. The $\mathrm{pH}$ optimum of crude xylanase was estimated by carrying out the reactions in the $\mathrm{pH}$ range of 
3.0-10.0 using different assay buffers, citrate buffer $(50 \mathrm{mM}, \mathrm{pH}$ 3-6), phosphate buffer (50 mM, pH 6-7.5), Tris- $\mathrm{HCl}$ (50 mM, pH 7.5-9), and glycine- $\mathrm{NaOH}$ buffer $(50 \mathrm{mM}, \mathrm{pH} 8.6-10)$ at $70^{\circ} \mathrm{C}$ for $20 \mathrm{~min}$. The enzyme activity obtained at the $\mathrm{pH}$ optimum was used to calculate the relative enzyme activity at other $\mathrm{pHs}$. The optimum $\mathrm{pH}$ of 6.5 was used to determine the optimum temperature for the crude xylanase. The optimal temperature for crude xylanase was obtained by performing the enzyme assays at different temperatures. The experiments were carried out in the temperature range of $40-90^{\circ} \mathrm{C}$ under assay conditions as described above.

Thermostability of xylanases was assessed by incubating the enzyme at different temperatures $50-100^{\circ} \mathrm{C}$ with increments of $10^{\circ} \mathrm{C}$ for a period of 19 days. Subsamples were removed at definite time intervals over the period of incubation. The residual activities were determined under optimum $\mathrm{pH}$ and temperature conditions using the DNSA method as described above. In all cases, the initial activity was assumed to be $100 \%$ and used to calculate the enzyme activities as percentages of the initial activity during the incubation period.

\section{Hydrolysis of Birchwood Xylan}

The hydrolysis of Birchwood xylan was carried out in $100 \mathrm{ml}$ conical flask containing $50 \mathrm{ml}$ sodium phosphate buffer $(50 \mathrm{mM}, \mathrm{pH} 6.5)$, $1 \mathrm{~g}$ xylan, $0.03 \%$ (w/v) sodium azide, and $20 \mathrm{U}$ xylanase/g xylan. The hydrolysis was performed for $48 \mathrm{~h}$ at different temperatures $\left(50,60\right.$, and $\left.70^{\circ} \mathrm{C}\right)$ with a rotating speed of $150 \mathrm{rpm}$. Hydrolysis of xylan was also compared using commercial enzyme mix, Cellic HTec2 (Novozymes) and Accellerase XY (Genencor). Optimum $\mathrm{pH}$ of 5.0 was used for commercial enzymes to compare their hydrolytic potential at different temperatures. The amount of reducing sugar was measured by using DNS method as described above.

\section{Results and Discussions}

Thermophilic bacteria are excellent source of thermostable xylanases, which have the potential to be utilized in lignocellulose hydrolysis (Bhalla et al., 2013, 2014a,b). Thermostable xylanases, optimally active at high temperatures and wide range of $\mathrm{pHs}$ are useful under harsh industrial processing conditions (Turner et al., 2007). The production of total extracellular proteins and enzymes when WSUCF1 was grown on xylan is shown in Figure S1A in Supplementary Material. In general, the increase in enzyme activity is associated with an increase in total extracellular protein. The WSUCF1 strain produced maximum crude xylanase activity $(14.6 \mathrm{U} / \mathrm{ml})$ on day 4 when the culture had nearly reached to plateau phase. Further increase in the extracellular crude xylanase activity as well as total protein even after cessation of growth could be due to lysis of cells, which led to outflow of proteins into growth medium. Figure S1B in Supplementary Material suggests that maximum growth of WSUCF1 was achieved in $\sim 60 \mathrm{~h}$. Data on crude xylanase activities from WSUCF1 were generated from culture supernatants and under unoptimized medium conditions; therefore, further experiments were performed to optimize the xylanase activity.

\section{Effects of Growth Medium pH and Temperature on Crude Xylanase Activity}

Effect of growth medium $\mathrm{pH}$ is shown in Figure 1A. The pHs 6.0 and 7.0 adequately supported the xylanase activity with maximum at $\mathrm{pH}$ 7.0. It declined sharply when the $\mathrm{pH}$ was either decreased or increased around the optima. At $\mathrm{pH} 6.0$, relative xylanase activity was $83 \%$ and it decreased to $30 \%$ at $\mathrm{pH} 8.0$ whereas $\mathrm{pH} 5.0$ and 9.0 did not support the production. It has been shown that growth medium $\mathrm{pH}$ strongly influences many enzymatic reactions by affecting the transport of a number of chemical products and enzymes across the cell membrane (Liang et al., 2010). Our results also confirmed that growth medium $\mathrm{pH}$ was an important factor affecting the crude xylanase activity in WSUCF1. Optimum xylanase activity near neutrality has been reported earlier for Bacillus sp. (Sapre et al., 2005), Bacillus SPS-0 (Bataillon et al., 2000), and Bacillus thermoleovorans strain K-3d (Sunna et al., 1997).

Growth medium temperature also impacted the production of xylanase activity (Figure 1B). WSUCF1 strain showed maximum amount of xylanase activity at $60^{\circ} \mathrm{C}$ and the activity decreased drastically when temperature was decreased below $55^{\circ} \mathrm{C}$ and increased above $65^{\circ} \mathrm{C}$. Most of the known xylanase producing microbes have optimum growth $\mathrm{pH}$ between 5.5 and 9.5 (Kulkarni et al., 1999). Optimum growth temperature of $60^{\circ} \mathrm{C}$ has been reported for Bacillus SPS-0 (Bataillon et al., 2000) and Bacillus stearothermophilus (Khasin et al., 1993). Bacillus thermantarcticus (Lama et al., 2004) and Bacillus sp. JB 99 (Shrinivas et al., 2010) grew optimally at 65 and $55^{\circ} \mathrm{C}$, respectively. Higher growth temperatures are industrially desirable because temperatures above $50^{\circ} \mathrm{C}$ could lead to significantly reduced risks of mesophilic microbial contamination (Yeoman et al., 2010).

\section{Effects of Different Lignocellulosic Materials on Crude Xylanase Activity Production}

The use of inexpensive agriculture residues as substrates for the production of industrial enzymes is a significant way to reduce cost of the overall process. WSUCF1 utilized a variety of inexpensive pretreated as well as untreated cellulosic substrates such as PCG, CS, PPCG, and PCS (Figure 2). Interestingly, in addition to xylan, all lignocellulosic substrates supported for xylanase activity. The crude xylanase activity was maximum $(23.8 \mathrm{U} / \mathrm{ml}, 100 \%)$ for Birchwood xylan, followed by untreated CS (88\%), untreated prairie cordgrass (84\%), PPCG (76\%), and PCS (72\%). CS contributes roughly up to $80 \%$ of all agricultural residues produced in USA therefore considered as a feedstock of choice for various applications, including lignocellulosic ethanol production (Kadam and McMillan, 2003; Zhu et al., 2006; Balan et al., 2009). Kim and Dale (2004) have reported an estimated ethanol production from CS, i.e., 38.4 billion liters of ethanol per year. On the other hand, perennial grasses like prairie cordgrass is also considered as one of the most abundant biomass feedstocks in the Great Plains (Gonzalez-Hernandez et al., 2009; Rastogi et al., 2010; Zambare et al., 2011). Brito-Cunha et al. (2013) reported high xylanases production utilizing sugarcane bagasse and wheat bran as substrates from Streptomyces sp. Thermophilic xylanolytic Thermoanaerobacter strains have also been reported to produce xylanases with poplar, spruce, miscanthus, wheat 

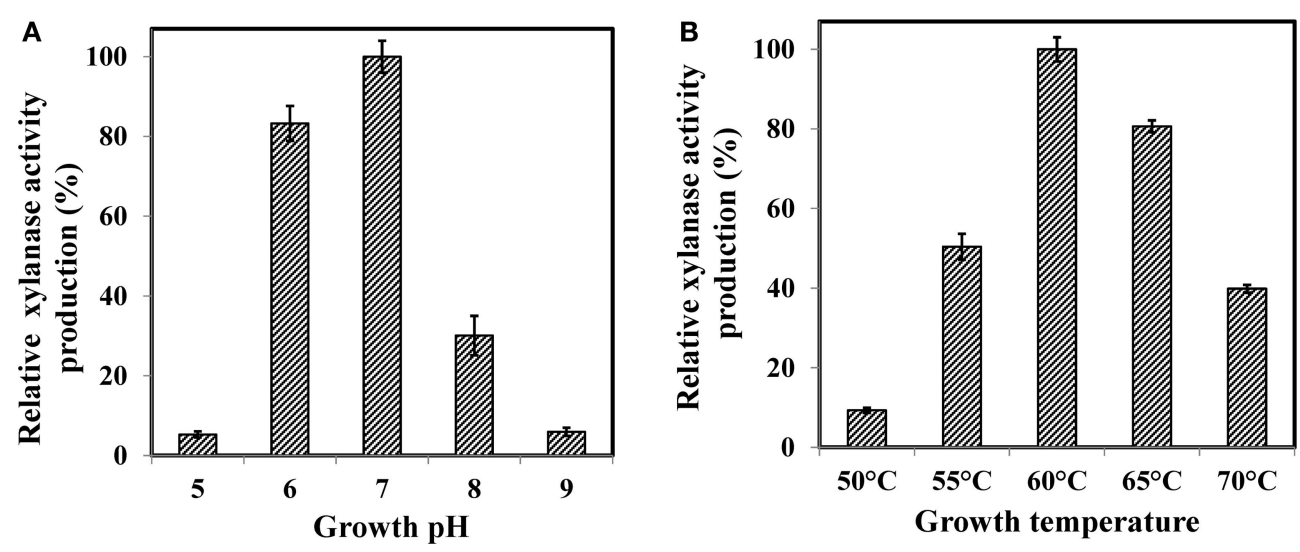

FIGURE 1 | Effect of (A) growth pH and (B) growth temperature on production of WSUCF1 xylanase. Enzyme production at optimum pH and optimum temperature was defined as $100 \%$ (19.3 and $18.7 \mathrm{U} / \mathrm{ml}$, respectively). Values shown were the mean of duplicate experiments, and the variation about the mean was below $5 \%$

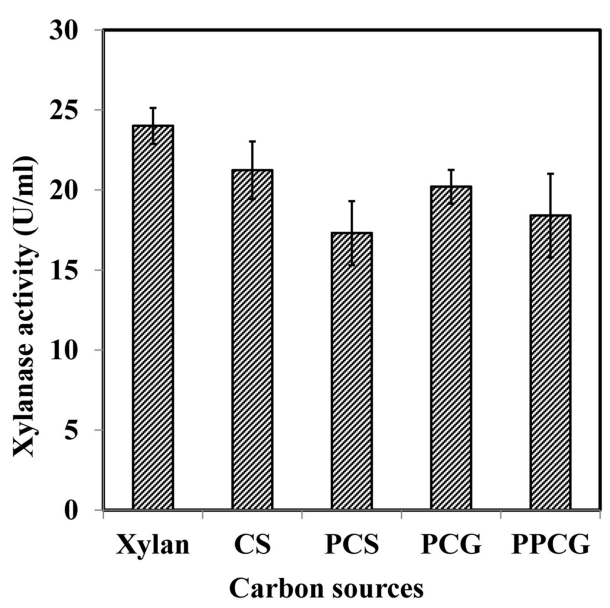

FIGURE 2 | Effects of xylan and various inexpensive lignocellulosics (prairie cordgrass - PCG, corn stover - CS, pretreated prairie cordgrass - PPCG, and pretreated corn stover - PCS) on xylanase production by WSUCF1.

straw, whole corn plants, corn cobs, corn stalks, sugarcane bagasse, sweet sorghum, or cotton stalks (Svetlitchnyi et al., 2013).

Literature shows that several microbial species have been reported to use lignocellulosics for xylanase production; however, there are not many reports on utilization of prairie cordgrass and CS as substrates. To reduce the cost of the enzymes needed for the hydrolysis, in-house production of xylanases on various substrates is beneficial. Producing thermostable lignocellulose deconstruction enzymes (crude xylanases) using untreated lignocellulosic biomasses (PCG and PCS) further shows the industrial potential of the WSUCF1 strain. The use of untreated lignocellulosic waste biomasses as substrates for the production of lignocellulolytic enzymes would have both economic and environmental advantages.

\section{Characterization of Thermostable Crude Xylanase Cocktail}

Crude xylanases were expressed at high levels in the production medium containing different carbon sources. A SDS zymogram analysis was performed to observe the expression of different xylanases in the crude extract obtained from the growth medium. Figure 3A demonstrates the activity bands for endoxylanase activity on OSX as substrate whereas Figure 3B shows $\beta$-xylosidase activity on 4 -methylumbelliferyl- $\beta$-d-xylopyranoside (MUX) as a specific substrate.

On analyzing the activity bands obtained for endoxylanase activity (Figure 3A), five prominent activity bands were observed at $60,45,38,34$, and $17 \mathrm{kDa}$ for the secretome obtained from growth on untreated CS whereas only two activity bands were obtained for PCS secretome, i.e., 34, and $17 \mathrm{kDa}$. Same trend was noticed for PCG where four activity bands were observed for untreated PCG $(45,38,34$, and $17 \mathrm{kDa})$ and two activity bands (34 and $17 \mathrm{kDa}$ ) for PPCG. On observing the activity bands for Birchwood xylan secretome, a high-density activity band smear was observed between 37 and $20 \mathrm{kDa}$. The observed trend very well explains the difference in expression of enzymes by a microbe when grown on differently treated complex substrates. On evaluating the activity bands obtained for $\beta$-xylosidase activity (Figure 3B), two bands were observed at 240 and $90 \mathrm{kDa}$ for the secretomes obtained from growth on lignocellulosic substrates, whereas interestingly, one different band of $160 \mathrm{kDa}$ along with $90 \mathrm{kDa}$ band was observed for the secretome obtained from growth on pure substrate, i.e., Birchwood xylan. These results demonstrate the importance of variations in the enzyme expression by the same bacterium on different substrates.

Another hypothesis was tested to correlate the enzyme expression observed from zymography experiment with the data obtained on crude xylanase activity (Figure 2). Results showed that higher enzyme units obtained on untreated CS and PCG were positively correlated to the number of active enzymes from untreated CS and PCG zymograms, whereas for pretreated material, lesser enzyme activity was correlated with less enzyme expression. 


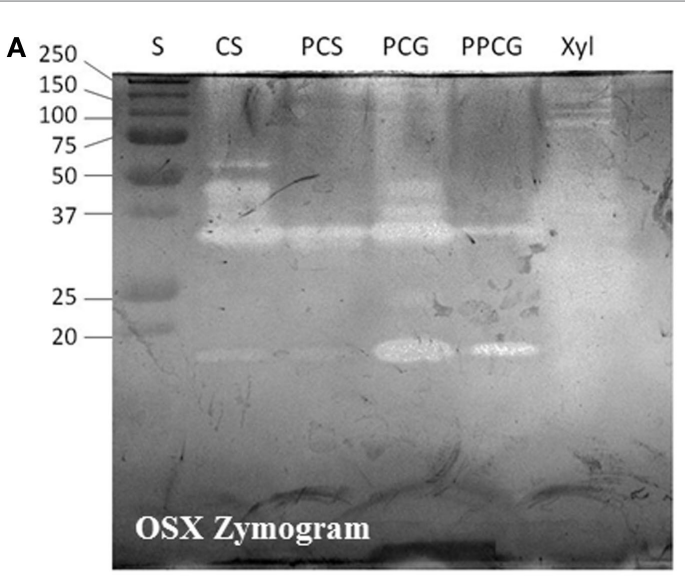

\begin{tabular}{|l|c|}
\hline Sample & $\begin{array}{c}\text { Masses(kDa) of } \\
\text { xylanase }\end{array}$ \\
\hline CS & $60,45,38,34,17$ \\
\hline PCS & 34,17 \\
\hline PCG & $45,38,34,17$ \\
\hline PPCG & 34,17 \\
\hline Xyl & High density between $37-20$ \\
\hline
\end{tabular}

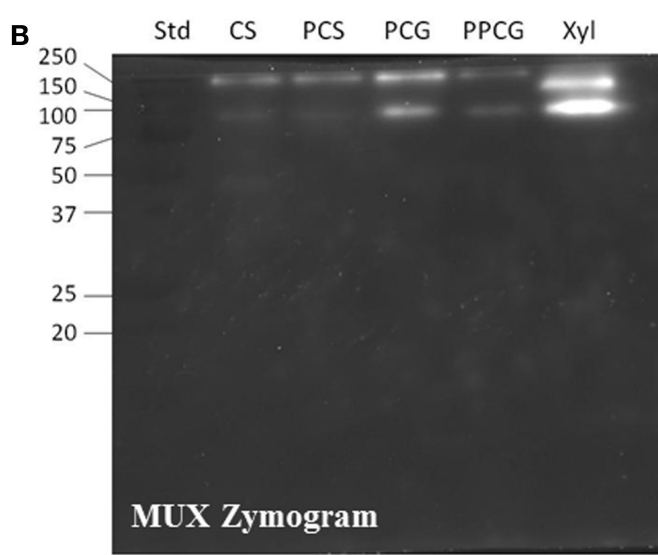

\begin{tabular}{|l|c|}
\hline Sample & $\begin{array}{c}\text { Masses(kDa) of } \\
\text { xylosidase }\end{array}$ \\
\hline CS & 240,90 \\
\hline PCS & 240,90 \\
\hline PCG & 240,90 \\
\hline PPCG & 240,90 \\
\hline Xyl & 160,90 \\
\hline
\end{tabular}

FIGURE 3 | SDS-PAGE (12\%) and zymogram of WSUCF1 (A) endoxylanase activity, (B) $\boldsymbol{\beta}$-xylosidase activity. Lane S, precision plus protein standards (BioRad); Lane CS, corn stover; Lane PCS, pretreated corn stover; Lane PCG, prairie cord grass; Lane PPCG; pretreated prairie cord grass.
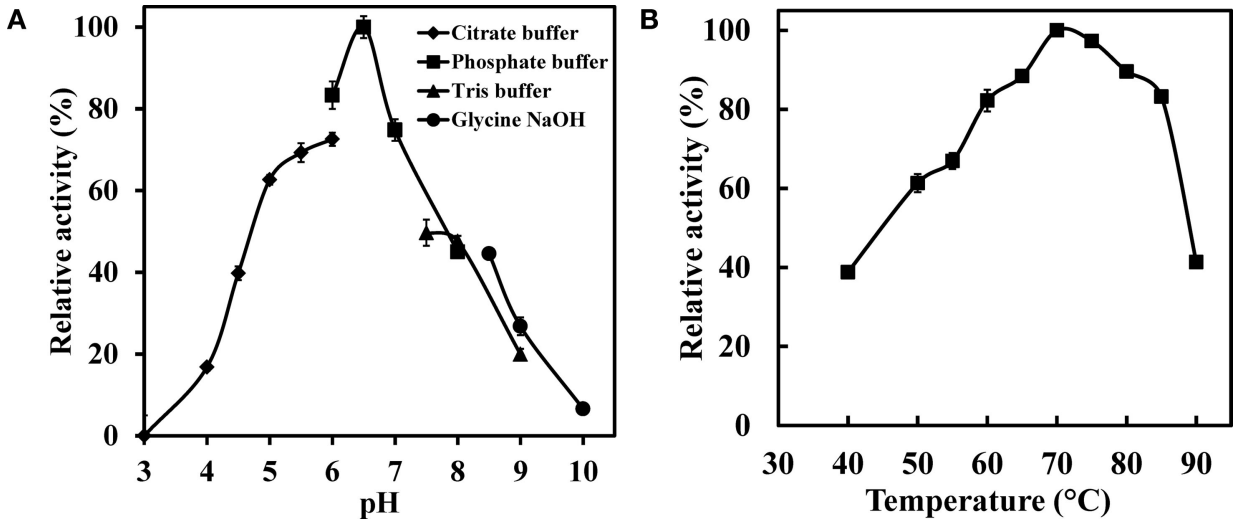

FIGURE 4 | Impact of (A) pH and (B) temperature on the xylanase activity of WSUCF1 isolate. The enzyme activity was expressed as percentages of the maximum activity. The points are the averages of triplicates, and error bars indicate \pm SDs of the means $(n=3)$. Error bars smaller than the symbols are not shown.

To further characterize the enzyme, effect of the $\mathrm{pH}$ on the WSUCF1 crude xylanase activity was examined from $\mathrm{pH} 3.0$ to 10.0 (Figure 4A). WSUCF1 produced maximum xylanase activity in sodium phosphate buffer at $\mathrm{pH}$ 6.5. WSUCF1 xylanase exhibited activity in broad $\mathrm{pH}$ range of 4.5-8.5 with more than $40 \%$ relative activity at $\mathrm{pH} 4.5$ and 8.5 . At $\mathrm{pH}$ range of 5.5-7.0, more than $70 \%$ relative activity was retained. Xylanases from Thermoanaerobacterium saccharolyticum NTOU1 (Hung et al., 2011), Clostridium sp. TCW1 (Lo et al., 2011), Actinomadura sp. S14 (Sriyapai et al., 2011), Bacillus sp. (Sapre et al., 2005), Bacillus flavothermus strain LB3A (Sunna et al., 1997), and
B. stearothermophilus T-6 (Khasin et al., 1993) also showed their $\mathrm{pH}$ optima at 6.0-7.0.

The impact of different temperatures on the xylanase activity is shown in Figure 4B. Maximum xylanase activity was observed at $70^{\circ} \mathrm{C}$. The xylanase activity increased linearly with increasing the temperature up to $70^{\circ} \mathrm{C}$ and thereafter it declined; however, at $85^{\circ} \mathrm{C}$ about $83 \%$ of its maximum activity was still retained. At lower temperatures, i.e., at 50 and $60^{\circ} \mathrm{C}, 61$ and $82 \%$ of maximum xylanase activity was observed, respectively. Xylanases from Geobacillus thermodenitrificans TSAA1 (Verma et al., 2013), Bacillus sp. JB 99 (Shrinivas et al., 2010), Bacillus licheniformis 
77-2 (Damiano et al., 2006), and B. flavothermus strain LB3A (Sunna et al., 1997) also showed their temperature optimum at $70^{\circ} \mathrm{C}$. Results demonstrated that WSUCF1 xylanase activity was resistant to change in temperature and hence it is well suited for the harsh process conditions that lignocellulose bioprocessing entails.

Thermal stability profile of WSUCF1 xylanase activity was also observed (Figure 5). Enzyme retained about $70 \%$ of its original activity after incubating the enzyme at $50^{\circ} \mathrm{C}$ for 19 days. At 60 and $70^{\circ} \mathrm{C}, 50 \%$ of xylanase activity was retained after incubation for 19 and 12 days, respectively. With further increase in the incubation temperature, decreased enzyme activity was observed. At 80 and $90^{\circ} \mathrm{C}$, complete enzyme activity was lost in 150 and $70 \mathrm{~min}$, respectively (data not shown). Xylanase from $G$. thermodenitrificans TSAA1 (Verma et al., 2013) retained $>85 \%$ activity after exposure to $70^{\circ} \mathrm{C}$ for only $180 \mathrm{~min}$, xylanase from Paenibacillus macerans IIPSP 3 exhibited half-life of $6 \mathrm{~h}$ at $60^{\circ} \mathrm{C}$ (Dheeran et al., 2012), Bacillus subtilis exhibited half-lives of $16.2,9.6$, and $2.8 \mathrm{~h}$ at 60,70 , and $80^{\circ} \mathrm{C}$, respectively (Saleem et al., 2012), and Enterobacter sp. MTCC 5112 retained 85 and $64 \%$ of its activity for $18 \mathrm{~h}$ at 60 and $70^{\circ} \mathrm{C}$, respectively (Khandeparkar and Bhosle, 2006). These results showed that WSUCF1 xylanase is highly thermostable as compared to the xylanases from other thermophiles. There is considerable interest in enzymes with high thermostability for industrial applications. There had been a number of studies published on enhancing thermal stability using genetic engineering. Stephens et al. (2009) reported the improvement in thermostability of xylanases from Thermomyces lanuginosus using error-prone PCR. Jeong et al. (2007) and Zhang et al. (2010) also reported improved thermostability in xylanases using site-directed mutagenesis whereas WSUCF1 is highly thermostable in its native form. Therefore, WSUCF1 xylanase warrants its application in biomass conversion processes, which are carried out at high temperatures.

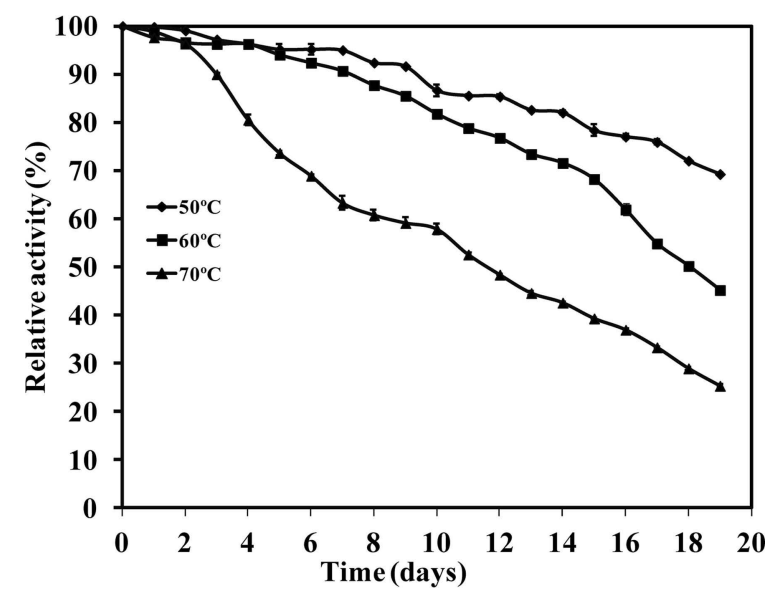

FIGURE 5 | Thermal stability of xylanase activity produced by WSUCF1 isolate. The enzyme activities were expressed as percentages of the initial activity. The points are the averages of triplicates, and error bars indicate \pm SDs of the means $(n=3)$. Error bars smaller than the symbols are not shown.

\section{Studies on Hydrolysis of Birchwood Xylan}

Thermostable enzymes that hydrolyze lignocellulose to sugars have significant advantages for improving the conversion rate of biomass over their mesophilic counterparts. The hydrolysis rates for WSUCF1 xylanase were higher at $70^{\circ} \mathrm{C}$ as compared to 50 and $60^{\circ} \mathrm{C}$. Figure 6 shows the comparison of hydrolytic capability of WSUCF1 xylanase, Cellic HTec2 (optimum temperature $50^{\circ} \mathrm{C}$ ) and Accellerase XY (optimum temperature $50^{\circ} \mathrm{C}$ ). It can be seen from the figure that in opposed to commercial enzymes, with increase in temperature from 50 to $70^{\circ} \mathrm{C}$ hydrolysis rates of WSUCF1 xylanase were increased. At $70^{\circ} \mathrm{C}$, higher conversions were obtained with WSUCF1 xylanase as compared to Cellic HTEc2 and Accellerase $\mathrm{XY}$ after $48 \mathrm{~h}$ of incubation. Percentage conversions were calculated on the basis of reducing sugars released from $1 \mathrm{~g}$ Birchwood xylan. At $70^{\circ} \mathrm{C}$, WSUCF1 xylanase yielded higher conversions of $68.9 \%$ as compared to Cellic HTec2 (49.4\%) and Accellerase XY (28.92\%). However, lower conversion rates were obtained with WSUCF1 as compared to Cellic HTec2 and Accellerase XY at $50^{\circ} \mathrm{C}$. The main objective of this experiment was to evaluate the potential of WSUCF1 xylanases at $70^{\circ} \mathrm{C}$.

He et al. (2009) reported that the recombinant Xyn2 hydrolyzed $<20 \%$ of Birchwood xylan when it was incubated at $50^{\circ} \mathrm{C}$, but the hydrolysis rates linearly increased with the increasing of reaction time. The xylanase from $B$. thermantarcticus hydrolyzed $70 \%$ of Birchwood xylan $(2 \% \mathrm{w} / \mathrm{v})$ within $24 \mathrm{~h}$ of reaction time at $70^{\circ} \mathrm{C}$, but the hydrolysis rates were $<40 \%$ at 60 and $80^{\circ} \mathrm{C}$ (Lama et al., 2004). Our xylan hydrolysis results show that WSUCF1 crude xylanase cocktail performed better than Cellic-HTec2 and Accellerase XY at $70^{\circ} \mathrm{C}$. These data suggest that xylanase cocktail produced by WSUCF1 strain is highly active and stable at high temperatures, and therefore, can be used as a part of the enzyme cocktail for efficient hemicellulose hydrolysis.

In summary, thermostable xylanases are the key enzymes for lignocellulosic deconstruction. The existing enzymatic hydrolysis

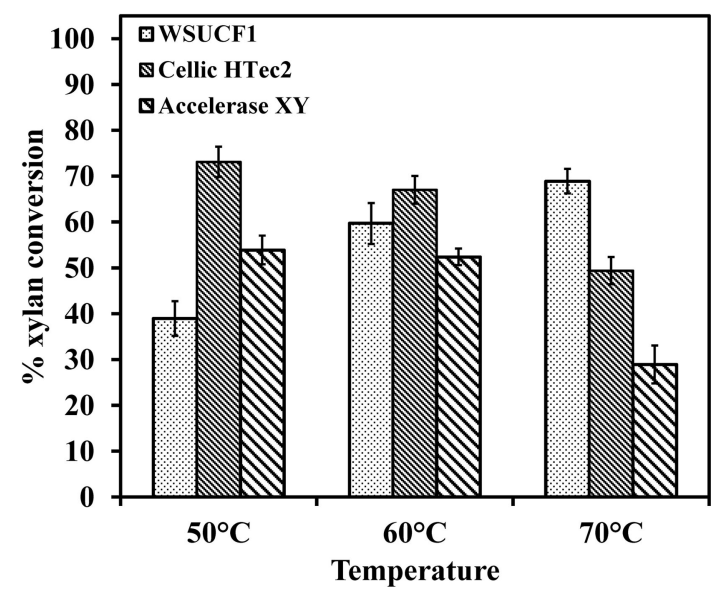

FIGURE 6 | Hydrolysis of Xylan from Birchwood - comparison of hydrolytic activity of WSUCF1 xylanase, Cellic HTec2, and Genencor Accellerase $\mathbf{X Y}$. The points are the averages of duplicates, and error bars indicate \pm SDs of the means $(n=2)$. Error bars smaller than the symbols are not shown. 
technologies of lignocellulose into sugars, which are carried out at $\leq 50^{\circ} \mathrm{C}$, have several limitations, including very slow enzymatic hydrolysis rates, low yields of sugars from lignocellulose (often incomplete hydrolysis), high dosages of enzymes, and microbial contamination problems. It has repeatedly been suggested that these limitations could be overcome using thermophiles and thermostable enzymes (Viikari et al., 2007; Yeoman et al., 2010; Bhalla et al., 2013, 2014a,b). For instance, Ovissipour et al. (2009) showed that rates of hydrolysis of protein hydrolyzate from Persian Sturgeon (Acipenser persicus) using Alcalase ${ }^{\mathrm{R}}$ were increased about three-times with increase in temperature from 35 to $55^{\circ} \mathrm{C}$. The fact that the strain WSUCF1 thermophile can utilize untreated lignocellulosic substrates to produce xylanases will likely play a key role in reducing production costs of the enzymes. The lowcost enzymes, if made available to biofuel industries, will enable economic conversion of biomass to biofuels. Removal of the CS, PCG, and other biomass wastes will provide a social benefit of protecting the environment and cleaner surroundings. The local CS and prairie grass producers will benefit from an additional and continued income source.

\section{Conclusions}

Geobacillus sp. WSUCF1 produced highly active crude xylanase cocktail when grown on inexpensive renewable untreated

\section{References}

Balan, V., Bals, B., Chundawat, S. P., Marshall, D., and Dale, B. E. (2009). Lignocellulosic biomass pretreatment using AFEX. Methods Mol. Biol. 581, 61-77. doi:10.1007/978-1-60761-214-8_5

Bataillon, M., Cardinali, A. P. N., Castillon, N., and Duchiron, F. (2000). Purification and characterization of a moderately thermostable xylanase from Bacillus sp. strain SPS-0.Enzyme Microb. Technol. 26, 187-192. doi:10.1016/S0141-0229(99)00143-X

Bhalla, A., Bansal, N., Kumar, S., Bischoff, K. M., and Sani, R. K. (2013). Improved lignocellulose conversion to biofuels with thermophilic bacteria and thermostable enzymes. Bioresour. Technol. 128, 751-759. doi:10.1016/j.biortech.2012.10.145

Bhalla, A., Bischoff, K. M., and Sani, R. K. (2014a). Highly thermostable GH39 $\beta$-xylosidase from a Geobacillus sp. strain WSUCF1. BMC Biotechnol. 14:963. doi:10.1186/s12896-014-0106-8

Bhalla, A., Bischoff, K. M., Uppugundla, N., Balan, V., and Sani, R. K. (2014b). Novel thermostable endo-xylanase cloned and expressed from bacterium Geobacillus sp. WSUCF1. Bioresour. Technol. 165, 314-318. doi:10.1016/j.biortech.2014.03.112

Brito-Cunha, C. C., de Campos, I. T., de Faria, F. P., and Bataus, L. A. (2013). Screening and xylanases production by Streptomyces sp. grown on lignocellulosic wastes. Appl. Biochem. Biotechnol. 170, 598-608. doi:10.1007/s12010-013-0193-3

Cano, À., and Palet, C. (2007). Xylooligosaccharide recovery from agricultural biomass waste treatment with enzymatic polymeric membranes and characterization of products with MALDI-TOF-MS. J. Membr. Sci. 291, 96-105. doi:10.1016/j. memsci.2006.12.048

Damiano, V. B., Ward, R., Gomes, E., Alves-Prado, H. F., and Da Silva, R. (2006). Purification and characterization of two xylanases from alkalophilic and thermophilic Bacillus licheniformis 77-2. Appl. Biochem. Biotechnol. 12, 289-302. doi:10.1385/ABAB:129:1:289

Dheeran, P., Nandhagopal, N., Kumar, S., Jaiswal, Y. K., and Adhikari, D. K. (2012). A novel thermostable xylanase of Paenibacillus macerans IIPSP3 isolated from the termite gut. J. Ind. Microbiol. Biotechnol. 39, 851-860. doi:10.1007/s10295-012-1093-1

Gao, D., Uppugundla, N., Chundawat, S. P., Yu, X., Hermanson, S., Gowda, K., et al. (2011). Hemicellulases and auxiliary enzymes for improved conversion of lignocellulosic biomass to monosaccharides. Biotechnol. Biofuels 4, 5 . doi:10.1186/1754-6834-4-5 feedstocks. The xylanase cocktail was found to be highly stable and active over wide range of $\mathrm{pH}$ and temperature. Zymography profiles showed an interesting correlation with the enzyme expression and differently treated or untreated lignocellulosic substrates. Higher xylan conversions were obtained at $70^{\circ} \mathrm{C}$ when compared with commercial enzymes. WSUCF1 crude xylanase is among the most thermostable xylanases produced by thermophilic Geobacillus spp. and other thermophilic microbes (optimum growth temperature $\leq 70^{\circ} \mathrm{C}$ ). These unique properties make WSUCF1 xylanases suitable for thermophilic lignocellulose bioconversion processes.

\section{Acknowledgments}

The authors gratefully acknowledge the financial support provided by National Science Foundation - Industry/University Cooperative Research Center (NSF-I/UCRC, Grant \# 441087). The support from the Department of Chemical and Biological Engineering at the South Dakota School of Mines and Technology is gratefully acknowledged.

\section{Supplementary Material}

The Supplementary Material for this article can be found online at http://journal.frontiersin.org/article/10.3389/fbioe.2015.00084

Gonzalez-Hernandez, J. L., Sarath, G., Stein, J. M., Owens, V., Gedye, K., and Boe, A. (2009). A multiple species approach to biomass production from native herbaceous perennial feedstocks. In vitro Cell. Dev. Biol. Plant 45, 267-281. doi:10.1007/ s11627-009-9215-9

He, J., Yu, B., Zhang, K., Ding, X., and Chen, D. (2009). Expression of endo-1, 4-beta-xylanase from Trichoderma reesei in Pichia pastoris and functional characterization of the produced enzyme. BMC Biotechnol. 9:56. doi:10.1186/1472-6750-9-56

Hung, K. S., Liu, S. M., Tzou, W. S., Lin, F. P., Pan, C. L., Fang, T. Y., et al. (2011). Characterization of a novel GH10 thermostable, halophilic xylanase from the marine bacterium Thermoanaerobacterium saccharolyticum NTOU1. Process Biochem. 46, 1257-1263. doi:10.1016/j.procbio.2011.02.009

Jeong, M. Y., Kim, S., Yun, C. W., Choi, Y. J., and Cho, S. G. (2007). Engineering a de novo internal disulfide bridge to improve the thermal stability of xylanase from Bacillus stearothermophilus no. 236. J. Biotechnol. 127, 300-309. doi:10.1016/j. jbiotec.2006.07.005

Jørgensen, H., Kristensen, J. B., and Felby, C. (2007). Enzymatic conversion of lignocellulose into fermentable sugars: challenges and opportunities. Biofuels Bioprod. Biorefin. 1, 119-134. doi:10.1002/bbb.4

Kadam, K. L., and McMillan, J. D. (2003). Availability of corn stover as a sustainable feedstock for bioethanol production. Bioresour. Technol. 88, 17-25. doi:10.1016/ S0960-8524(02)00269-9

Kannadhason, S., Muthukumarappan, K., and Rosentrater, K. A. (2009). Effects of ingredients and extrusion parameters on aqua feed containing DDGS and tapioca starch. J. Aquac. Feed Sci. Nutr. 1, 6-21.

Khandeparkar, R., and Bhosle, N. B. (2006). Purification and characterization of thermoalkalophilic xylanase isolated from the Enterobacter sp. MTCC 5112. Res. Microbiol. 157, 315-325. doi:10.1016/j.resmic.2005.12.001

Khasin, A., Alchanati, I., and Shoham, Y. (1993). Purification and characterization of a thermostable xylanase from Bacillus stearothermophilus T-6. Appl. Environ. Microbiol. 59, 1725-1730.

Kim, S., and Dale, B. E. (2004). Global potential bioethanol production from wasted crops and crop residues. Biomass Bioenergy 26, 361-375.

Kulkarni, N., Shendye, A., and Rao, M. (1999). Molecular and biotechnological aspects of xylanases. FEMS Microbiol. Rev. 23, 411-456. doi:10.1111/j.1574-6976.1999. tb00407.x 
Kumar, R., Singh, S., and Singh, O. (2008). Bioconversion of lignocellulosic biomass: biochemical and molecular perspectives. J. Ind. Microbiol. Biotechnol. 35, 374-379. doi:10.1007/s10295-008-0327-8

Laemmli, U. K. (1970). Cleavage of structural proteins during the assembly of the head of bacteriophage T4. Nature 227, 680-685. doi:10.1038/227680a0

Lama, L., Calandrelli, V., Gambacorta, A., and Nicolaus, B. (2004). Purification and characterization of thermostable xylanase and beta-xylosidase by the thermophilic bacterium Bacillus thermantarcticus. Res. Microbiol. 155, 283-289. doi:10.1016/j. resmic.2004.02.001

Liang, Y., Feng, Z., Yesuf, J., and Blackburn, J. W. (2010). Optimization of growth medium and enzyme assay conditions for crude cellulases produced by a novel thermophilic and cellulolytic bacterium, Anoxybacillus sp. 527. Appl. Biochem. Biotechnol. 160, 1841-1852. doi:10.1007/s12010-009-8677-x

Lo, Y. C., Huang, C. Y., Cheng, C. L., Lin, C. Y., and Chang, J. S. (2011). Characterization of cellulolytic enzymes and bioH2 production from anaerobic thermophilic Clostridium sp. TCW1. Bioresour. Technol. 102, 8384-8392. doi:10.1016/j.biortech.2011.03.064

Ovissipour, M., Abedian, A., Motamedzadegan, A., Rasco, B., Safari, R., and Shahiri, H. (2009). The effect of enzymatic hydrolysis time and temperature on the properties of protein hydrolysates from Persian sturgeon (Acipenser persicus) viscera. Food Chem. 115, 238-242. doi:10.1016/j.foodchem.2008.12.013

Paes, G., and O'Donohue, M. J. (2006). Engineering increased thermostability in the thermostable GH-11 xylanase from Thermobacillus xylanilyticus. J. Biotechnol. 25, 338-350. doi:10.1016/j.jbiotec.2006.03.025

Qing, Q., and Wyman, C. E. (2011). Supplementation with xylanase and $\beta$-xylosidase to reduce xylo-oligomer and xylan inhibition of enzymatic hydrolysis of cellulose and pretreated corn stover. Biotechnol. Biofuels 4, 18. doi:10.1186/1754-6834-4-18

Rastogi, G., Bhalla, A., Adhikari, A., Bischoff, K. M., Hughes, S. R., Christopher, L. P., et al. (2010). Characterization of thermostable cellulases produced by Bacillus and Geobacillus strains. Bioresour. Technol. 101, 8798-8806. doi:10.1016/j. biortech.2010.06.001

Rastogi, G., Muppidi, G. L., Gurram, R. N., Adhikari, A., Bischoff, K. M., Hughes, S. R., et al. (2009). Isolation and characterization of cellulose-degrading bacteria from the deep subsurface of the Homestake gold mine, Lead, South Dakota, USA. J. Ind. Microbiol. Biotechnol. 36, 585-598. doi:10.1007/s10295-009-0528-9

Saleem, M., Aslam, F., Akhtar, M. S., Tariq, M., and Rajoka, M. I. (2012). Characterization of a thermostable and alkaline xylanase from Bacillus sp. and its bleaching impact on wheat straw pulp. World J. Microbiol. Biotechnol. 28, 513-522. doi:10.1007/ s11274-011-0842-z

Sapre, M. P., Jha, H., and Patil, M. B. (2005). Purification and characterization of a thermoalkalophilic xylanase from Bacillus sp. World J. Microbiol. Biotechnol. 21, 649-654. doi:10.1007/s12010-010-8980-6

Shrinivas, D., Savitha, G., Raviranjan, K., and Naik, G. R. (2010). A highly thermostable alkaline cellulase-free xylanase from thermoalkalophilic Bacillus sp. JB 99 suitable for paper and pulp industry: purification and characterization. Appl. Biochem. Biotechnol. 162, 2049-2057. doi:10.1007/s12010-010-8980-6

Sriyapai, T., Somyoonsap, P., Matsui, K., Kawai, F., and Chansiri, K. (2011). Cloning of a thermostable xylanase from Actinomadura sp. S14 and its expression in Escherichia coli and Pichia pastoris. J. Biosci. Bioeng. 111, 528-536. doi:10.1016/j. jbiosc.2010.12.024
Stephens, D. E., Singh, S., and Permaul, K. (2009). Error-prone PCR of a fungal xylanase for improvement of its alkaline and thermal stability. FEMS Microbiol. Lett. 293, 42-47. doi:10.1111/j.1574-6968.2009.01519.x

Sunna, A., Prowe, S. G., Stoffregen, T., and Antranikian, G. (1997). Characterization of the xylanases from the new isolated thermophilic xylan-degrading Bacillus thermoleovorans strain K-3d and Bacillus flavothermus strain LB3A. FEMS Microbiol. Lett. 148, 209-216. doi:10.1111/j.1574-6968.1997.tb10290.x

Svetlitchnyi, V. A., Kensch, O., Falkenhan, D. A., Korseska, S. G., Lippert, N., Prinz, M., et al. (2013). Single-step ethanol production from lignocellulose using novel extremely thermophilic bacteria. Biotechnol. Biofuels 6, 31 . doi:10.1186/1754-6834-6-31

Turner, P., Mamo, G., and Karlsson, E. N. (2007). Potential and utilization of thermophiles and thermostable enzymes in biorefining. Microb. Cell Fact. 6, 9. doi:10.1186/1475-2859-6-9

Verma, D., Anand, A., and Satyanarayana, T. (2013). Thermostable and alkalistable endoxylanase of the extremely thermophilic bacterium Geobacillus thermodenitrificans TSAA1: cloning, expression, characteristics and its applicability in generating xylooligosaccharides and fermentable sugars. Appl. Biochem. Biotechnol. 170, 119-130. doi:10.1007/s12010-013-0174-6

Viikari, L., Alapuranen, M., Puranen, T., Vehmaanperä, J., and Siika-Aho, M. (2007). Thermostable enzymes in lignocellulose hydrolysis. Adv. Biochem. Eng. Biotechnol. 108, 121-145.

Yeoman, C. J., Han, Y., Dodd, D., Schroeder, C. M., Mackie, R. I., and Cann, I. K. (2010). Thermostable enzymes as biocatalysts in the biofuel industry. Adv. Appl. Microbiol. 70, 1-55. doi:10.1016/S0065-2164(10)70001-0

Zambare, V. P., Bhalla, A., Muthukumarappan, K., Sani, R. K., and Christopher, L. P. (2011). Bioprocessing of agricultural residues to ethanol utilizing a cellulolytic extremophile. Extremophiles 15, 611-618. doi:10.1007/ s00792-011-0391-2

Zhang, Z. G., Yi, Z. L., Pei, X. Q., and Wu, Z. L. (2010). Improving the thermostability of Geobacillus stearothermophilus xylanase XT6 by directed evolution and site-directed mutagenesis. Bioresour. Technol. 101, 9272-9278. doi:10.1016/j. biortech.2010.07.060

Zhu, Y., Kim, T. H., Lee, Y. Y., Chen, R., and Elander, R. T. (2006). Enzymatic production of xylooligosaccharides from corn stover and corn cobs treated with aqueous ammonia. Appl. Biochem. Biotechnol. 12, 586-598. doi:10.1385/ ABAB:130:1:586

Conflict of Interest Statement: The authors declare that the research was conducted in the absence of any commercial or financial relationships that could be construed as a potential conflict of interest.

Copyright (C) 2015 Bhalla, Bischoff and Sani. This is an open-access article distributed under the terms of the Creative Commons Attribution License (CC BY). The use, distribution or reproduction in other forums is permitted, provided the original author(s) or licensor are credited and that the original publication in this journal is cited, in accordance with accepted academic practice. No use, distribution or reproduction is permitted which does not comply with these terms. 